\title{
The Importance of Thinking Skills for Islamic Education
}

\author{
Meithiana Indrasari ${ }^{1}$, Bambang Raditya ${ }^{2}$, Bambang Purnomo ${ }^{3}$, Iwan Sugianto ${ }^{4}$, Lusiana \\ Prastiwi $^{5}$ \\ \{meithiana.indrasari@unitomo.ac.id ${ }^{1}$, bambang.raditya.purnomo@unitomo.ac.id², \\ bambang.purnomo@unitomo.ac.id $\left.{ }^{3}\right\}$ \\ ${ }^{1,2,3,4,5}$ Dr. Soetomo University Surabaya, Indonesia
}

\begin{abstract}
This study aims to determine the important role of thinking skills for Islamic education. The method used library research. Data collection uses documentation and data analysis with descriptive analysis. The results showed that thinking skills play an important role in Islamic education as a reflection to benefit or learn from the information and our experiences. In Islamic Education, the reflection is better known as muhasabah. Muhasabah is the process of thinking or examining what has been done throughout the day. The role of muhasabah in Islamic education is to review the behavior and change it to a better direction and this will determine the success of the transfer process of values to students.
\end{abstract}

Keywords: Thinking skills, islamict education, information, knowledge.

\section{Introduction}

Someone can be said to learn if the knowledge and information they have brings a change to individuals who learn. Changes are not only about the amount of knowledge gained, but also in the form of skills, habits, attitudes, understanding, appreciation, interests, adjustments and self-behavior. By learning, we are more able to face difficulties in solving problems or adjusting to circumstances and also applying that knowledge functionally in living situations [1]. Lifelong learners or lifelong learners is a concept of continuing-learning from the cradle to the end of life, in line with the phases of development in humans. Imam Ahmad said:

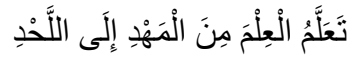

Meaning: Learn knowledge from (since) swing to the grave.

Learning is done so that we can fulfill the developmental tasks that go through starting from childhood to adulthood and even old age. The developmental tasks that we will face include choosing friendships or social groups, seeking self-potential, adjusting to physical changes and increasing age, choosing a spouse, work, and facing changes in old age.

To increase the ability to become a lifelong learner, we need a variety of life skills, which in fact we have not fully obtained in school. The knowledge and information we get today are mostly final traits, many of which stop as the knowledge that is (memorized) [2]. One of the main capital is the knowledge and information that we have. We have a lot of sources of knowledge and information in our lives, ranging from learning outcomes in 
schools, books, internet, discussions and seminars, and other sources, but often we still find it difficult to use it to face challenges and changes in life in this age.

\section{Literatur review}

\subsection{Information, knowledge and process thinking}

Information is a set of correct data (not opinions or gossip) that have meaning or meaning for us to accept. Knowledge is some information received by the brain to be processed and digested, then we begin to choose which information is important or useful for the brain to be stored. Then the brain will give an attitude about what we must do. In transforming information into knowledge there is one other process that needs to be done, namely the thought process. The process of thinking is a behavioral process using the mind to seek meaning and understanding something, make judgments and decisions or resolve problems [3].

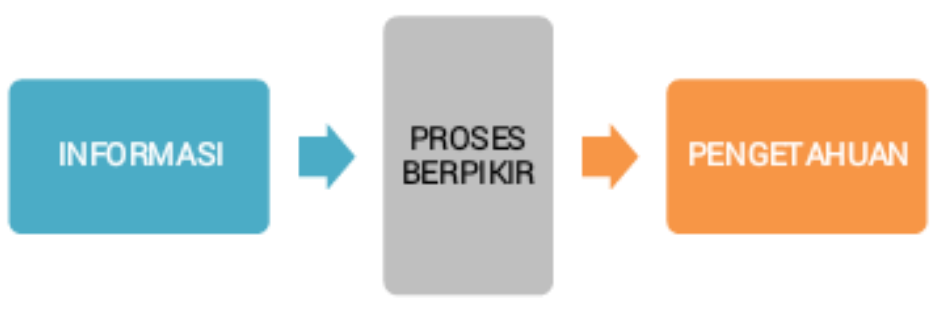

Fig. 1. Information Process Becomes Knowledge (in bahasa)

The process of thinking is an activity in the cognitive domain of humans. Cognitive is one domain in the human body that includes mental activity (brain). All efforts concerning brain activity are included in the cognitive domain. Cognitive aspects oriented to thinking abilities that include intellectual abilities, namely remembering, up to problem-solving skills that require us to connect and combine some information in the form of ideas, ideas, methods or procedures learned to solve these problems [4]. Someone will think usually because there is a problem that is happening to him, for example: when someone is losing money, then he will think, open his memory, remember, find out, or arrange the sequence of what was done before to find the lost money.

\subsection{Inability thinking}

Thinking inability is possible in various fields of life. Symptoms of inability to think, one of which can be shown by people who say, behave and behave in a hurry without weighing the benefits. One of the causes of inability to think can also result in violence, we cannot afford to think fairly, clearly, and be critical of self-beliefs [5]. People who don't want to think, tend to be lazy to think. He will think and behave according to what others think and do. If you face problems, often he will look for instant solutions, or always ask for help from others. Humans who grow up with such characters, tend to be humans who are not opinionated and not independent.

Examples of cases that we can meet for example, when a parent or teacher explains a concept or explains the resolution of a problem, then the child responds, "Already ma'am, direct the answer or how to do it." Such dialogue will bring up indications of lazy thinking in 
children. On the other hand, in another episode, when the child asks the parent or teacher, "How can it be obtained that way, ma'am?" The parent or teacher answers, "Already, just memorize the formula" or "Just do what Mom says, no ask questions. On the other hand, the behavior of the parent or teacher shows behavior that will trigger the behavior of inability and lazy thinking for the child.

The inability to think can also be demonstrated by impatience in carrying out the process. At home or in class, for example, children cannot wait to follow the process of how knowledge is built, easily give up and ask for help from others so that the work is completed quickly. Meanwhile, parents or teachers also do not carry out a learning process to guide children to build their understanding [6]. For example, when children spill water on the floor, parents often immediately take responsibility for cleaning the water, this is done so that it 'finishes quickly', while events like this are very good at training children to be able to think, how to clean the wet floor, use any tool or how to not spill again while building a sense of responsibility for his actions.

If this is not trained and parents only hope that their children succeed without regard to the learning process, then thinking skills will not be built. Television shows also contribute greatly to shaping the behavior of unwillingness to think or lazy to think. Not a few shows that show success can be achieved by shortcuts that negate the process. Shows like this will enter his memory and if remembered, they can form clear perceptions.

\subsection{Thinking ability needs to be trained}

Most of us often assume that someone will have the ability to think on their own. If we give certain information we "think" that other people must understand, because information and advice have been given in normal, easy-to-understand Indonesian. We "think" that other people would want to do it because it's good for them. But in reality, it is not always the case. We need to practice thinking skills to process information into useful knowledge for ourselves. Some of the meanings that we need to understand in practicing thinking skills are:

a. Thinking skills are not automatically owned by someone

b. Thinking skills are not a direct result of teaching a field of study, or by getting an education in school. Even though they have participated in certain subjects such as Science, Social Sciences, Mathematics or others, it does not directly produce students who are capable of thinking. For example, in one of the science subjects in Elementary School, there was material about waste, the cause of waste littering, how to manage garbage at home, etc. But in reality, we still meet children who throw litter, even up to adults. This means that the material only stops at the understanding of INFORMATION, it has not become KNOWLEDGE, because there is no change in attitude to maintain cleanliness by removing garbage in its place. Just interpreting the lesson as a material that needs to be 'memorized' only.

c. Teaching thinking skills requires a learning model that is centered on the person we are going to train, not enough teachers or parents only give lectures or advice that are only listening and centering on the 'giver' of the lecture.

d. Thinking skills require continuous and intensive training until we become skilled. Like other skills, in thinking skills, we need to repeat to train it [7]. 


\subsection{Thinking skills}

Thinking skills are mental processes that are applied to help solve problems, make decisions, arrange questions, develop plans, plan, update ideas, get information or create objects. Thinking skills will help us to learn more from the information and experiences we experience and make us better at using intelligence [8]. Thinking skills will also equip us for life, allowing us to understand our own potential and give approval to the community. Benefits of training.

a. Manage information into knowledge, so as to build attitudes, values, skills to solve problems.

b. Reflect on the experiences that have occurred and occur, reflect on the causes and consequences, and resolve the solution.

c. Develop a habit of asking about the manifestation of the criticality of our thinking about an event and a phenomenon that occurs in society, both in the past, present and future.

d. Making reflections, interpreting experience and information, so that we do not only memorize in taking the learning process.

e. Train to find the connection between our experiences with one another, even with something that happens in the community, so that we use those who draw conclusions in every experience that occurs in our lives [9].

\subsection{Importance of thinking skills in islamic education}

In the Qur'an, there are many verses that invite people to think. How many sentences invite people to think are listed in the verse. Allah does not want us to stop at the reading process, but we must proceed to the thought process. Like the word of Allah in the letter Al An'am verse 50

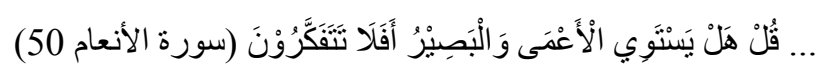

Meaning: Say (Muhammad) is it the same with people who are blind to those who see? So did you not think (of) [10].

This sentence stimulates humans to use their mind and mind and how to utilize the gifts of the brain that have been given by Allah SWT, stimulate humans to use their mind and mind. Thinking skills are the elaboration of the sentences above.

Table 1. Embodiment of Thinking Skills

\begin{tabular}{cl}
\hline No & Embodiment of Thinking Skills \\
\hline 1 & Search for data and information \\
2 & Looking for alternatives \\
3 & Solve the problem \\
4 & Make the decision \\
5 & Asking question \\
6 & Build a plan \\
7 & Explore and evaluate ideas \\
8 & Manage information \\
9 & Creating objects \\
10 & Draw conclusions \\
11 & Take lessons/wisdom \\
\hline
\end{tabular}


When the brain has received information, we are invited to process it, take actions such as continuing the message, examining the truth or seeking wisdom. These steps trigger us as people to race to use the mind's mind to complete responsibilities on earth [11].

It is stated that the thinking process is a reflection to take advantage of or learn from the information and experiences we experience. The concept of self-reflection in Islam already exists and is known as muhasabah. Muhasabah means a process to practice, think, or examine what has been done throughout the day. The aim of Muhasabah itself is to review behavior and change it in a better direction. The Prophet Muhammad himself asserted that a smart person is someone who keeps thinking and preparing for his death [12]. It was narrated from Rasulullah SAW:

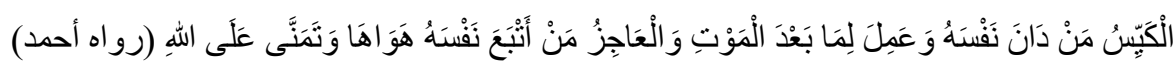

Meaning: A smart person is a person who corrects himself and acts charity after death. And the fool is one who follows his passions and hopes for Allah's forgiveness.

To maximize this process, our thinking skills will be very helpful to find the best wisdom in every step of life.

Like quotes of wise words:

"The cause of failure is largely due to two things, namely people who think but never act and people who act but never think."

\subsection{Some types of thinking skills}

Thinking skills help us to recognize problems, how to identify actual problems, what situations we face and must be resolved. The introduction of this problem helps us to be able to focus on the goals to be achieved in solving the problem. Then we will find it easier to find out what obstacles we need to overcome and how to overcome them in achieving that goal.

Thinking skills are divided into several types of categories, including the following:

a. Problem-solving skills (problem-solving), namely skills in using thinking processes to solve problems through gathering facts, analyzing information, compiling various alternative solutions, and choosing the effective problem-solving.

b. Decision-making ability, namely individual skills in using thought processes to choose the best decision from several choices available through information gathering, comparison of the good and shortcomings of each alternative, analysis of information, comparison of cause and effect and the best decision making based on rational reasons.

c. The ability to think critically (critical thinking), critical thinking is the ability to gather various information and make a conclusion from an activity. The activity includes the process of analyzing, explaining, developing or selecting ideas, categorizing, comparing and determining priorities and making positive choices. By thinking critically, a person is spared from various attempts at deception, manipulation, duping, and deception. Avoid various mistakes, such as wasting time, money, and involving emotions in beliefs or teachings or wrong and misleading dogmas or ideologies.

d. Creative thinking skills. The ability to think creatively is the ability to cultivate the mind to produce new and constructive ideas, based on information, concepts, and rational principles as well as individual perceptions and intuition [13].

Thinking skills are not separate but integrated with one another. So at the same time, we use our thinking skills to solve problems but also use skills to make positive decisions, think critically, and think creatively. Examples of applying everyday thinking skills: 
Table 2. Application of Thinking Skills

\begin{tabular}{|c|c|c|c|}
\hline Problem solving skills & Decision making ability & $\begin{array}{c}\text { Ability } \\
\text { critical thinking }\end{array}$ & $\begin{array}{c}\text { Skills } \\
\text { creative thinking }\end{array}$ \\
\hline $\begin{array}{l}\text { The food parcel that I have } \\
\text { to send falls on the road, } \\
\text { while I have to get to the } \\
\text { destination within } 5 \text { hours? }\end{array}$ & $\begin{array}{l}\text { I will choose YES or } \\
\text { NO, when offered } \\
\text { smoking? }\end{array}$ & $\begin{array}{l}\text { I was offered a position } \\
\text { that was 'wet' and could } \\
\text { produce large material } \\
\text { within } 6 \text { months? }\end{array}$ & $\begin{array}{l}\text { I have not got a job, } \\
\text { what should I do? }\end{array}$ \\
\hline \multicolumn{4}{|c|}{ What will be done? (response if you are reluctant to think) } \\
\hline Sorry, will send late. & $\begin{array}{l}\text { YES answer, because of } \\
\text { solidarity and cannot } \\
\text { refuse. }\end{array}$ & $\begin{array}{l}\text { Directly interested and } \\
\text { accepting the position. }\end{array}$ & $\begin{array}{l}\text { Try several ways and } \\
\text { give up. }\end{array}$ \\
\hline \multicolumn{4}{|c|}{ Or use thinking skills to answer the challenge ... } \\
\hline $\begin{array}{l}\text { Collection of facts and } \\
\text { information: food falls, } 5 \\
\text { hours left, must be sent on } \\
\text { time, can it be repaired or } \\
\text { remade at that time? } \\
\text { Arrange various alternative } \\
\text { solutions: if made again, } \\
\text { which place is closest, } \\
\text { which path is smooth, etc. } \\
\text { and choose the effective } \\
\text { problem solving according } \\
\text { to the information they have }\end{array}$ & $\begin{array}{l}\text { Information analysis: } \\
\text { what are the benefits, } \\
\text { what are the } \\
\text { consequences if I use } \\
\text { and do not use? } \\
\text { Comparing good } \\
\text { comparison bad cause } \\
\text { and effect: smoking } \\
\text { gives benefits or bad } \\
\text { Choosing the best } \\
\text { decision from several } \\
\text { information choices: if } \\
\text { you reject what } \\
\text { happened, a lot of good } \\
\text { or bad }\end{array}$ & $\begin{array}{l}\text { Analyzing information: } \\
\text { is there a quick position } \\
\text { like that? } \\
\text { Explain, develop or } \\
\text { select: request concrete } \\
\text { explanations, look for } \\
\text { evidence, seek } \\
\text { information from } \\
\text { various sources } \\
\text { regarding similar } \\
\text { positions and the risks } \\
\text { borne } \\
\text { Categorize comparing } \\
\text { and determining } \\
\text { priorities: finding } \\
\text { information on } \\
\text { positions that have been } \\
\text { successful and } \\
\text { unsuccessful }\end{array}$ & $\begin{array}{l}\text { Gathering information: } \\
\text { what ways have I done } \\
\text { and haven't done? How } \\
\text { many ways have I tried? } \\
\text { Just a little or a lot? } \\
\text { Cultivate the mind to } \\
\text { generate new ideas: } \\
\text { what do others do? Can } \\
\text { I imitate or modify it? } \\
\text { what new ways can I do } \\
\text { and have not been } \\
\text { thought of by others? }\end{array}$ \\
\hline
\end{tabular}

\subsection{How to improve thinking skills}

Thinking can be improved like other skills. The benefits of developing thinking skills include improving performance; easier to interact in social life; improving emotional intelligence, for example, decreases aggressive, irritable tendencies and other negative tendencies, creative and constructive, and so on. Some studies show that if someone thinks positively and effectively then pain, anger, and aggressive tendencies will decrease significantly.

What can be done to improve thinking skills:

a. Step 1. Recognize the Conditions of How We Think. Recognizing how we think is the first step before we can change or improve the way we think. Get to know our current way or condition of thinking. We certainly will find it difficult to improve ourselves if we do not know what deficiencies we must improve, or the strength that we can improve. Then we will find a way to change it. 


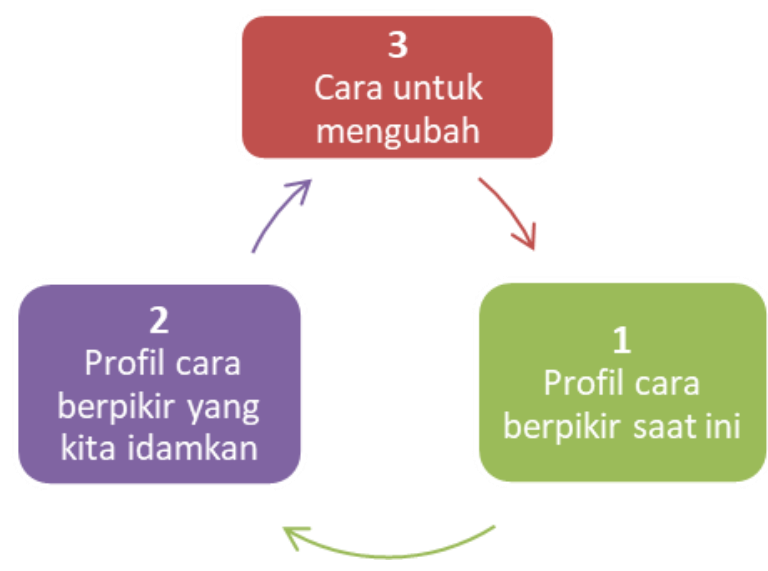

Fig. 1. Kondisi Saat Kita Berpikir (in Bahasa)

b. 2. Step 2. Take Time / Stop for a moment. When we have a problem, take time to pause for a moment, then take a few breaths to get oxygen. A moment's silence is an attempt to first "steal time" so that negative emotions don't overwhelm us first. When oxygen enters our body, it can facilitate blood flow to the brain and make it easier for us to think more clearly.

c. 3. Step 3. Information Exploration. After we are calmer, look for various information about the problem we are facing, it might be better for us to do more processing and exploration about the information we have. The more information we collect, the more alternative solutions we will get. Here we can extract information from discussions, interviews, textbooks, the internet or other sources.

d. 4. Step 4. Information Selection. Then the selection of information that we have collected, adjusts to our needs. The information chosen should be directed to the focus of the problems or challenges we are facing.

e. 5. Step 5. Sharpen the Questioning Skills. Asking questions may be something that looks simple, but this questioning skill requires practice in order to stimulate thinking skills, help achieve goals and focus the power of memory in a problem. From the information, we have made various questions. These questions will facilitate and train us to think more deeply, determine right wrong, look for cause and effect, sort out badly, making it easier for us to process information, manage emotions and find solutions.

f. 6. Step 6. Practice Focusing on Something. Then, find out what is the focus of the problem we are facing. For example, a few days the child is reluctant to go to school for no apparent reason, often we become emotional and cause negative emotions to emerge. Before negative emotions arise, try to focus on the problem and use the information we have, find the root of the problem, so we will be easier to find a way out without having to provoke angry emotions.

g. 7. Step 7. Reflection. Reflection trains us to draw conclusions, get insights or 'AHA' or wisdom from an experience that we have been through. Looking back at the parts where we have difficulties, in which part we are the easiest to do, how we solve the problem and develop steps for future improvement. 


\section{Conclusion}

Building a Husnudhon attitude is one of the characteristics of the basic attitude of Muslims. Therefore all human potential that exists in humans can be used to realize one of these basic attitudes. Systematic thinking and using it appropriately can improve our problemsolving capacity. Thinking ability can be improved according to the needs of its use, both to find alternative solutions to problems or when formulating problems, then when formulating a problem it can be correct, then alternative solutions are also correct, then life will be more blessed because it can be efficient in various circumstances. If there is an increase in the capacity to solve problems or problems, then it will increase the opportunity to do good deeds for the interests of many people, in an effort to help solve the problems that are being faced which may require assistance, as one manifestation of noble character and at the same time. We become human lifelong learners who are easy to find wisdom in every step of life.

In accordance with the scope of our respective responsibilities we are strived to be accustomed to using the information to knowledge, then from the knowledge, we will find a way of acting in an effort to carry out our responsibilities, then develop Husnudhon's attitude towards the results later.

\section{References}

[1] R. W. Dahar, Teori-Teori Belajar. Jakarta: Penerbit Erlangga, 1989.

[2] G. M. Bodner, "Constructivism: A Theory of Knowledge," J. Chem. Educ., vol. 63, 1986.

[3] Djamarah and B. Saiful, Psikologi Belajar. Jakarta: Rineka Cipta, 2002.

[4] P. Paulina and I. Malati, Strategi Kognitif. Jakarta: Direktorat Jendral Pendidikan Tinggi Departemen Pendidikan Nasional, 1997.

[5] E. M. Gredler, Learning and Instruction. Teori dan Aplikasi. Jakarta: Kencana, 2011.

[6] T. M. McDevitt and J. E. Ormrod, Child development: Educating and working with children and adolescents, 2nd ed. Upper Saddle River: Pearson Merrill Prentice Hall, 2002.

[7] E. R. H., Goals for A Critical Thinking I Curriculum. Developing Minds A Resource Book for Teaching Thinking. Virginia: Association for Suopervisions and Curriculum Development, 1985.

[8] J. W. Santrock, Educational Psychology. New York: McGraw Hill, 2011.

[9] Sadia, "Pengembangan Model Belajar Konstruktivis dalam Pembelajaran IPA di Sekolah Menengah Pertama," Program Pascasarjana IKIP Bandung, 1996.

[10] Depag RI, Al-Qur'an dan Terjemahannya. Bandung: Diponegoro, 2004.

[11] Muhaimin, Pemikiran Pendidikan Islam, Kajian Filosofis dan Karangka Dasar Oprasionalnya. Bandung: Triganda Karya, 1993.

[12] I. Bawani, Cendikiawan Muslim dalam Perspektif pendidikan Islam. Surabaya: Bina Ilmu Offset, 1991.

[13] R. S. Putra, Desain Belajar Mengajar Kreatif Berbasis Sains. Yogyakarta: Diva Press, 2013. 